\title{
STRATEGI RELOKASI PEDAGANG KAKI LIMA (PKL) DI TAMAN SULIKAN KABUPATEN LUWU UTARA
}

\author{
Nurlela $^{1}$, Mappamiring ${ }^{2}$, Muhammad Tahir ${ }^{3}$ \\ 1) Jurusan Ilmu Administrasi Negara Unismuh Makassar \\ 2) Jurusan Ilmu Adminisitrasi Negara Unismuh Makassar \\ 3) Jurusan Ilmu Administrasi Negara Unsimuh Makassar
}

\begin{abstract}
ABSTRACK
This research aimed to explain how far the goverment's strategy for the relocation of Pedagang Kaki Lima in Sulikan's garden North Luwu Regency and made it to be the icon of Masamba City of North Luwu Regency. Sulikan's garden had the strategic location for Pedagang Kaki Lima to sell their trades. The goverment relocated PKL because they were bothering and preventing, therefore PKL moved from Sulikan's garden to the Market of Masamba which its location were far from Sulikan's garden. The source of this data were a primary data that was collected by an interview and direct observation of the informant, a secondary data were a documents or written and unwritten reports. Techniques data analysis applied in this research are an interview, observation, and documention.

The data validity techniques used were triangulation of time, triangulation of data sources, and triangulation of theory. The result of the research showed that the goverment's strategy for relocation and regualtion of $\mathrm{PKL}$ used five indicators 1) mission framing 2) objective and strategy 3) funtion systems and, 4) culture groups. 1) approval alocation 2) modals allocation and 3) facilities and infrastructures allocation.
\end{abstract}

Keywords: strategy to relocate Pedagang Kaki Lima

\begin{abstract}
ABSTRAK
Tujuan penelitian ini adalah membahas tentang sejauh mana Strategi Pemerintah dalam melakukan Relokasi Pedagang Kaki Lima di Taman Sulikan Kabupaten Luwu Utara dan menjadikan taman sulikan sebagai Ikon Kota Masamba Kabupaten Luwu Utara. Taman sulikan merupakan lokasi strategis para pedagang kaki lima dalam mendagang kan dagannya. karena menganggu dan menghalangi maka pemerintah merelokasi pedagang yang dari awalnya berada di taman sulikan di ahlikan ke pasar sentral masamba yang berlokasi jauh dari taman sulikan. Sumber data yang digunakan yaitu, data primer yang berupa hasil wawancara dan pengamatan langsung kepada informan, data sekunder yaitu, data yang di peroleh melalui dokumen-dokumen atau laporan-laporan tertulis dan tidak tertulis. Jenis penelitian ini menggunakan teknik analisis data dengan melakukan wawancara, observasi, dan dokumentasi. Teknik keabsahan data yang digunakan adalah triangulasi waktu, triangulasi sumber data dan triangulasi teori setelah. Hasil penelitian ini menunjukkan bahwa strategi pemerintah dalam merelokasi pedagang kaki lima dan penataan pedagang kaki lima menggunakan indikator 1) penyusunan misi, 2) tujuan dan strategi, 3) sistem fungsi dan, 4) kelompok budaya. 1) pemberian izin usaha, 2) pemberian modal dan 3) pemberian sarana dan prasarana.
\end{abstract}

Kata Kunci: Strategi Merelokasi Pedagang Kaki Lima 


\section{PENDAHULUAN}

Permasalahan PKL ini runtut sejak awal dan semakin besar serta tidak mudah teratasi akibat kurangnya lapangan pekerjaan. Kebijakan telah diterapkan pemerintah khususnya pemerintah Kabupaten Luwu Utara dalam Perda No 02 Tahun 2011 Rencana Tata Ruang Wilaya Kabupaten Luwu Utara pasal (5) ayat (1) tahun 2011 yaitu "menudukung penetapan kota masamba sebagai PKL sesuai dengan Rencana Tata Ruang Wilaya Propinsi Sulawesi Selatan”. Proses implementasi kebijakan yang dilakukan oleh Pemerintah kabupaten luwu utara belum berjalan dengan baik, terutama dalam tahap-tahap pelaksanaannya dan tidak adanya koordinasi yang dilakukan antar instansi terkait dengan masyarakat dan pedagang kaki lima. Pedagang kaki lima (PKL) semakin tumbuh pesat dan berkembang secara besar dikawasan kota Masamba Kabupaten Luwu Utara. Di tengah permasalahan yang ada pemerintah setempat membuat kebijakan untuk mengsistemasikan keberadaan mereka menjadi agenda proritas penting bagi pemerintah baru di Kabupaten Luwu Utara. Salah satunya adalah upaya untuk merelokasi PKL yang semakin tumbuh pesat dikhawatirkan dapat membuat infrastruktur kota menjadi disfungsi sehingga disediakan tempat berjualan yang lebih kolektif disekitar kawasan Taman Lestari Sulikan.

Dengan ditetapkannya perda mengenai PKL, yang termuat dalam representasi dari Perpres No 125 Tahun 2012 tentang Penetapan, Pembinaan dan Pemberdayaan Pedagang Kaki Lima Dan Pemendagri No 41 Tahun 2012 tentang Penetapan dan Pemberdayaan PKL yaitu: Dalam Peraturan Presiden Mengenai Pedagang Kaki Lima (PKL) yaitu: Penetapan pedagang kaki lima (PKL) dalam pasal 2 dan 3 yaitu: pemerintahan bersama pemerintah daerah berkoordinasi melakukan penataan dan pemberdayaan PKL. Dan dalam pasal 3 menyebutkan Koordinasi penataan PKL sebagaimana dimaksud dalam pasal 2 yaitu, dilaksanakannya melalui: 
Pendataan dan pendaftaran PKL, Penetapan lokasi PKL,

Menurut Bromley, sebagaimana dikutip oleh Muliyanto dalam skripsi Muhammad (2015) pedagang kaki lima (PKL) merupakan kelompok tenaga kerja yang banyak di sektor informal. Pekerjaan pedagang kaki lima merupakan jawaban terakhir yang berhadapan dengan proses urbanisasi yang berkaitan dengan migrasi dari desa ke kota yang besar, pertumbuhan penduduk yang pesat, pertumbuhan kesempatan kerja yang lambat di sektor industri, dan penyerapan teknologi yang padat moral, serta keberadaan tenaga kerja yang berlebihan. Istilah kaki lima diambil dari pengertian tempat di tepi jalan yang lebarnya (5 feet).

Tempat ini umunya terletak ditrotoar depan toko dan tepi jalan. Ada pun ciri-ciri pedagang kaki lima ialah: Kegiatan usaha, tidak terorganisir secara baik Tidak memiliki surat izin usaha, Tidak teratur dalam kegiatan usaha, baik ditinjau dari tempat usaha maupun jam kerja, Bergerombol di trotoar, atau di tepi-tepi jalan protokol, di pusat-pusat dimana banyak orang ramai, Menjajakan barang dagangannya sambil berteriak, kadang-kadang berlari mendekati konsumen.

Masalah pedagang kaki lima ini merupakan masalah yang tidak bisa dilepaskan dari masalah ledakan penduduk dari suatu pertumbuhan perkotaan, sebagian besar mereka tergolong dalam masyarakat dari lapisan ekonomi yang rendah, dalam struktur ekonomi dan sosial indonesai. Ciri khas yang menonjol dari kelompok ini ialah ketidak teraturan mereka dalam menjajakan dagangannya, yang secara hukum sebenarnya melanggar ketentuan yang berlaku. Beberapa kota besar di Indonesia sering di jumpai pengangguran dan pengangguran tersembunyi dalam jumlah besar.

Menurut Jhingan ( 2014) Pengangguran dikota membengkak seiring dengan banyaknya urbanisasi dan meningkatnya biaya pendidikan. Akan tetapi sektor industri tidak berkembang sejalan dengan pertumbuhan tenaga kerja, sehingga memperbesar jumlah pengangguran. Disamping itu ada pula penganggur yang berpendidikan. Mereka gagal 
mendapatkan pekerjaan karena tegarnya struktur dan tiadanya perencanaan tenaga kerja. Dengan tingkat pertembuhan rata-rata tahunan penduduk kota sebesar $4,5 \%, 20 \%$ adalah penganggur. Pengganguran setiap masyarakat bangsa menghadapi masalah pengangguran masalah pengngguran dalam arti bahwa ada sekelompok warga masyarakat yang tidak mempunyai pekerjaan, dan memilih menjadi pedagang kaki lima (PKL) yang menjadi sumber penghasilannya.

Menurut Makmur ( 2009:3) pengangguran dibagi menjadi beberapa bagian yaitu:Pengangguran Terbuka Pengangguran terbuka ialah masyarakat yang tidak mempunyai pekerjaan sama sekali dan begantung kepadapihak lain seperti pemerintah melalui bentuk program kesejahteraan social, pemeliharaan orang-orang terlantar, yatim piatu, orang-orang yang tidak mempunyai keluarga untuk mengurusnya. Disamping pengangguran terbuka, terdapat pula pengangguran terselubung. Yang dimaksud dengan pengangguran terselubung ialah situasi masyarakat yang memliki pekerjaan tidak produktif. Pengangguran musiman adalah pengangguran yang lumrah /dialami oleh masyarakat dengan keterampilan yang hanya dapat di manfaatkan untuk bekerja pada karya yang tersedia secara terbatas pada waktu tertentu. Akibat banyak nya jumlah penganggurn mengakibatkan jumlah pedagang kaki lima makin bertambah tiap tahunnya, pedagang kaki lima (PKL) merupakan alternative yang di gunakan masyarakat untuk memenuhi kebutuhan ekonominya.

Menurut Mc Gee dan yeung (1997:76) dalam Jurnal Tia Marlinda (2010) pola ruang aktivitas PKL di pengaruhi oleh aktivitas sektor formal dalam menjaring konsumenya. Lokasi PKL sangat dipengaruhi oleh hubungan langsung dan tidak langsung dengan berbagai kegiatan formal dan kegiatan informal atau hubungan PKL dengan konsumenya. Untuk dapat mengenali penataan ruang kegiatan PKL, maka harus mengenal aktivitas PKL melalui pola penyebaran, pemanfaatna ruang berdasarkan 
waktu berdagang dan jenis dagangan serta sarana berdagang. Penanganan masalaah pedagang kaki lima (PKL) menjadi hal yang meresahkan saat ini, terutama bagi pemerintah daerah, baik pemerintah kota maupun pemerintah kabupaten.

Penanganan yang sebaiknya dilakukan dengan penanganan yang berdampak positif kepada banyak pemerintah, PKL itu sendiri dan masyarakat. Tidak dapat dipungkiri bahwa profesi PKL menjadi suatu mata pencarian dikala seseorang tidak punya pekerjaan atau tidak dapat ditampung dalam sektor

formal. Densgan demikian pemerintah, baik pemerintah pusat maupun pemerintah daerah harus

segera membuat strategi pembangunan PKL. Sebagai bagian dari pembagunan sektor informal dalam rangka penganggulangan kemiskinan di perkotaan.

Ada beberapa strategi yang dikembangkan dalam penataan pedagang kaki lima (PKL) sehingga kawasan kota tetap asri dalam bentuk pemberdayaan yaitu: Pemberian Izin Usaha, Pemberian Modal, dan Pemberian Sarana dan Prsarana.
Beberapa pakar dalam ilmu manajemen mendefiniskan manajemen startegi dengan cara yang berbedabeda. Sala satu definisnya menyebutkan manajemen strategi sebagai satu kumpulan keputusan dan tindakan yang menghasilkan

keputusan dalam penempatan kebijakan dan implementasi dibentuk dalam meraih tujuan perusahaan (Pearce II dan Robinson, 2008:3) dalam buku Sedarmayanti (2014). Manajemen stsartegi terdiri atas sembilan tugas penting yaitu:

Merumuskan misi perusahaan, termasuk pernyataan yang luas mengenai maksud filosofi, dan saran perusahaan, Melakukan suatu analisis yang mencerminkan kondisi dan kapabilitas internal perusahaan,

Menilai lingkungan eksternal perusahaan, termasuk faktor persaingan dan faktor kontekstual umum lainnya, Menganalisis pilihanpilihan yang dimiliki oleh perusahaan dengan cara menyesuaikan sumberdayanya dengan lingkungan eksternal, Mengidentifikasi pilihan paling menguntungkan dengan cara mengevaluasi setiap pilihan 
berdasarkan misi perusahaan, Memilih satu set tujuan jangka panjang dan strategi utama yang akan menghasilkan pilihan paling menguntukan tersebut.

$$
\text { Certo (2010:5) dalam }
$$

buku Sedarmayanti

mendefinisikan manajemen strategis sebagai analisis, keputusan dan aksi yang dilakukan perusahaan untuk menciptakan dan mempertahankan ke unggulan kompetitif. Defenisi ini menggambarkan dua elemen utama manajemen strategis. Elemen pertama, manajemen strategis dalam sebuah perusahaan berkaitan dengan proses berjalan (ongoing processes): analisis, keputusan, dan tindakan.

Manajemen strategis berkaitan dengan bagaimana manajemen menganalisis sasaran strategis (visi, misi, tujuan) serta kondisi internal dan eksternal yang dihadapi perusahaan. Selanjutnya perusahaan harus menciptakan keputusan strategis. Keputusan ini harus mampu menjawab dua pertanyaan utama, yakni industri apa yang digeluti perusahaan dan bagaimana perusahaan harus bersaing di industri tersebut. Terakhir, tindakan yang perlu diambil untuk menjalankan keputusan tersebut. Tindakan yang perlu dilakukan akan mendorong manajer untuk mengalokasikan sumber daya dan merancang organisasi untuk mengubah rencana menjadi kenyataan. Elemen kedua, manajemen strategis adalah studi tentang mengapa perusahaan mampu mengalahkan perusahaan lainnya.

$$
\text { Manajer perlu menetukan }
$$
bagaimana perusahaan bisa menciptakan keunggulan kompetitif yang tidak hanya unik dan berharga, tetapi juga sulit ditiru atau dicari subtitusinya sehingga mampu bertahan lama. Keunggulan kompetitif yang mampu bertahan lama biasanya didapatkan dengan melakukan aktivitas berbeda degan apa yang di lakukan pesaing, atau melakukan aktivitas yang sama dengan cara yang berbeda. Manajemen strategi merupakan proses atau rangkaian kegiatan pengambilan keputusan yang bersifat mendasar dan menyeluruh, disertai penetapan cara melaksanakannya, yang dibuat oleh pimpinan dan diimplementasikan oleh seluruh jajaran di dalam suatu organisasi, 
untuk mencapai tujuan. Pengertian Manajemen Strategi Manajemen strategis yang terdapat dalam buku Eddy Yunus (2016:16). pada seluruh ruang lingkup pekerjaannya, dengan demikian dapat dimanfaatkan secara baik untuk lingkungan makronya,

\section{METODE PENELITIAN}

Penelitian ini mengambil lokasi di Taman Sulikan Kabupaten Luwu Utara, dengan alasan untuk mengetahui bagaimana relokasian pedangan kaki lima (PKL) di Taman Sulikan Kabupaten Luwu Utara. Jenis penelitian yang digunakan adalah kualitatif yaitu bertujuan untuk mengumpulkan data dan informasi dari sejumlah informan

kunci yang dianggap dapat memberikan informasi yang berhubungan dengan masalah penelitian relokasi Pedagang Kaki Lima di Taman Sulikan Kabupaten Luwu Utara. Tipe penelitian ini adalah tipe deskriptif kualitatif, tipe penelitian ini menggambarkan kejadian secara umum mengenai masalah yang diteliti yaitu: relokasi Pedagang Kaki Lima di Taman Sulikan Kabupaten Luwu Utara.
Data Primer yaitu data yang

di peroleh langsung melalui penelitian, yang berupa hasil wawancara atau pengamatan kepada para informan. Data sekunder yaitu data yang di peroleh melalui dokumen-dokumen atau laporanlaporan tertulis dan tidak tertulis Adapun teknik pengempulan data dalam penelitian ini adalah Pengamatan (Observasi) Observasi, yaitu pengumpulan data yang dilakukan dengan cara melakukan pengamatan langsung terhadap relokasi Pedagan Kaki Lima (PKL) di Taman Sulikan Kabupaten Luwu Utara Wawancara yaitu mengajukan pertanyaan langsung kepada infroman yang berkaitan dengan relokasi Pedagang Kaki Lima (PKL) di Taman Sulikan Kabupaten Luwu Utara.

Dokumentasi adalah pengumpulan data dengan meneliti catatn-catatn penting yang sangat erat hubungannya dengan objek yang diteliti.Teknik keabasahan data Salah satu cara untuk menguji keabsahan data Triangulasi adalah gabungan atau kombinasi berbagai metode yang dipakai untuk mengkaji 
fenomena yang saling terkait dari sudut pandang dan prespektif yang berbeda. Triangulasi meliputi empat hal, yaitu: triangulasi metode, triangulasi antar-peneliti, triangulasi sumber data dan triangulasi teori.

\section{HASIL DAN PEMBAHASAN}

Gambaran umum objek penelitian yaitu Dinas Lingkungan Hidup. Dinas Lingkungan Hidup merupakan Instansi Pemerintahan yang bertugas dalam kelestarian kawasan Kabupaten Luwu Utara dan menciptakan kearsian, keindahan, dan kerapian (3K). Dinas Pekerjaan

Umum dan Penataan Ruang merupakan Instansi Pemerintahan yang bertugas dalam pembangunan infrastruktur kota dan Pembangunan Ruang Tata Hijau yang terdapat di Taman Sulikan Kabupaten Luwu Utara. Satpol PP merupakan Satuan Polisi Pamong Praja yang bertugas dalam penertiban masyarakat serta dalam keamanan suatu daerah, Pamong Praja atau Satpol PP merupakan Aparat Kepolisian yang membantu Kerja Pemerintah Daerah Kabupaten Luwu Utara dalam menciptakan daerah yang religius, tentram dan aman. Ketiga Instasi Pemerintahan tersebut terletak pada Daerah Baliase Jalan Simpursiang Kota Masamba Kabupaten Luwu Utara Sulawesi Selatan yang merupakan arah Jalan Poros Luwu Timur Masamba sebagai Ibu Kota Dari Kabupaten Luwu Utara yang memiliki berbagai keberagaman penduduk yang membuka lapangan pekerjaan tersendiri dalam meningkatkan perekonomian keluarganya. Pedagang kaki lima di Luwu Utara bisa dikatan telah menyebar disetiap pinggir jalan Kota Masamba Kabupaten Luwu Utara. Keberadaan pedagang kaki lima ini menyebabkan banyaknya kawasan yang merupakan area larangan berdagang dijadikan sebagai lapak berjualanya sehingga Sepanjang jalan yang terdapat di Masamba Kabupaten Luwu Utara terdapat berbagai pedagang yang menempati area trotoar jalan. Terutama yang terdapat pada area Taman Sulikan berbagai jenis pedagang menjajakan daganganya pada area tersebut. Adapun ragam pedagang yang terdapat di taman sulikan kabupaten luwu utara sebagai 
berikut: Pedagang ikan sekitar berjumlah 7-10 oran, Jajanan ringan sekitar 8-10 orang, Gorengan sekitaran 5 orang, Jus atau minuman sekitaran 9 orang.

Pedagang yang terdapat Ditaman Sulikan merupakan Warga Luwu Utara dan sebagian warga yang merupakan luar dari Daerah Luwu Utara yang mendagangkan daganganya pada area taman sulikan. Berbagai himbauan telah disampaikan oleh Dinas terkait dalam pemindahan atau relokasi pedagang kaki lima yang awalnya berada diarea taman sulikan dipindahkan ke area pasar sentral yang merupakan area baru yang dibuat oleh pemerintah setempat sebagai tempat berdaganya. Pro

kontra antara pedagang dan Pemerintah Kabupaten Luwu Utara yang berkembang saat ini menunjukan suatu indikasih ketidak puasan PKL terhadap Kebijakan Pemerintah dalam merelokasi PKL. Lokasi yang diharpkan oleh PKL adalah lokasi yang sama strategisnya dengan tempat awal mereka berdagang. Strategis disini diartikan sebagai lokasi yang potensial untuk penghidupan mereka. Artinya bahwa kebijakan tersebut hendaknya tidak mengurangi subtansi kesejahteraan bagi PKL

$$
\text { Banyaknya jumlah }
$$

pertumbuhan penduduk menyebabkan kurangnya lapangan pekerjaan yang tersedia di kabupaten luwu utara. Secara Administrasi terdiri 12 Kecamatan 167 Desa dan 4 Kelurahan. Penduduknya berjumlah 250.111 Jiwa (2003) atau sekitar 50.022 kepala keluarga yang sebagian besar $(80,93 \%)$ bermata pencaharian sebagai petani, pedagang dan pegawai Penduduk Luwu Utara hingga tahun 2016 berjumlah 363.741 jiwa. Berdasarkan data yang dirilis Dinas Kependudukan dan Pencatatan Sipil (Dukcapil) Luwu Utara. Jumlah penduduk hingga akhir 363.741 penduduk hingga akhir tahun 2017. Banyaknya pertumbuhan penduduk mengkibatkan melonjaknya Pertumbuhan ekonomi di Luwu Utara sampai akhir tahun 2017 mencapai 7,49 persen. Capalan tersebut meningkat dibandingkan pertumbuhan ekonomi tahun 2016 yang hanya sebesar 6,66 persen. 
Pertumbuhan ini didorong kinerja lapangan usaha yang dilakukan oleh Masyarakat Luwu Utara. usaha kecilkecilan yang dilakukan Mayarakat Luwu Utara pada tiap tahunnya selalu meningkat yang dari $45 \%$ menjadi $53 \%$ pertahun dimana usaha yang ditekuni masayarakat merupakan usaha perdagangan atau bisnis yang hampir sebagian dari Masyarakat Luwu Utara telah menekuninnya. Visi dan Misi Kabupaten Luwu Utara Paradigma baru memandang pertumbuhan Ekonomi bukan merupakan satusatunya tujuan, akan tetapi lebih merupakan proses untuk mencapai tujuan pembangunan Daerah itu sendiri maksimal dengan memperhatikan potensi Daerah secara obyektif serta Visi Kabupaten Luwu Utara. Visi yang dicita-citakan kedepan akan bertumpu pada upaya meletakkan landasan pembangunan yaitu:

Visi : Mewujudkan Masyarakat Luwu Utara yang religius, maju, sejahtera dan mandiri diatas landasan agribisnis dan ekonomi kerakyatan. Misi. Meningkatkan Pelaksanaan Fungsi-
Fungsi Pemerintah, Meningkatkan fungsi dan peran kelembagaan

Daerah serta tata Organisasi Pemerintah Daerah dalam penyelenggaraan pembangunan secara mandiri, Mewujudkan kemitraan pembangunan, dengan merajut jalinan kerjasama antara

Pemerintah Daerah dengan Pemerintah Pusat, Pemerintah Provinsi Sulawesi Selatan, Pemerintah Kabupaten/ Kota Seprovinsi dan dengan Provinsi lainnya; antara Pemerintah Daerah dengan masyarakat, swasta/ pengusaha/ pebsinis, dan LSM dalam lingkungan wilayah Kabupaten Luwu Utara secara luas dalam upaya menumbuhkan perekonomian, pemerataan kutubkutub ekonomi wilayah dan pertumbuhan wilayah secara umum, Meningkatkan kemandirian keuangan dan pembiyaan pembangunan khususnya dalam meraih PAD, Mewujudkan pemerintah yang bersih dan baik, sehingga kepercayaan masyarakat akan semakin meningkat pula, Meningkatkan sumber daya alam yang terkait dengan potensi objek 
dan daerah tujuan wisata, khusunya wisata alam, Meningkatakan kualitas dan kuantitas perencanaan dibidang perkebunan, Meningkatkan kualitas dan kuantitas pemanfaatan sumber daya hutan, khususnya hasil hutan nirkayu secara optimal dan berwawasan lingkungan, Membina kelembagaan pemerintah dan masyarakat dalam pengerakan hukum dan penglolaan sumber daya alam dan pelestarian lingkungan hidup, Membangun sistem pengelolaan, penaggulangan dan mitigasi bencana alam, Pedagang kaki lima dalam menjajakan dagangganya biasanya memanfaatkan lahan kosong atau trotoar jalan sebagai lapak berjualnnya, sehingga menyebabkan para pejalan kaki tidak dapat menikmati kenyamanan trotoar jalan akibat pedagang kaki lima. Pedagang kaki lima biasanya melakukan aktivitas berdagangnya pada pagi hari mulai dari jam 9 pagi sampai jam 5 sore terkadang ada juga pedagang yang berjulan hingga larut malam. Sebagian dari pedagang kaki lima menggunakan grobak jalan dan mendirikan tenda-tenda bongkar pasang disetiap trotoar jalan Taman Sulikan.

Pedagang kaki lima kerap tidak menjaga kebersihan trotoar jalan yang berada disekitaran taman, dan menyebabkan Tata Ruang Hijau yang dibagun pemerintah tidak begitu nampak keasriannya. Taman Sulikan dibagun pemerintah dijadikan sebagai Aikon Kota Kabupaten Luwu Utara, akan tetapi ada beberapa pedagang kaki lima yang memanfaatkan sekitaran kota yang merupakan area larangan berjualan dijadikan sebagai lapak berdaganggnya, dan membuat pemerintah melakukan relokasi pedagang kaki lima ke Pasar Sentral Masamba sebagai lokasi baru berdaganggnya. Sebagaian pedagang yang berada ditaman sebelumnya sudah pindah lokasi akan tetapi ada sebagian pedagang yang nakal yang kerap enggan meninggalkan lokasi awal berjualanya.

Beberapa kali satuan satpol PP melakukan himbauan kepada para pedagang kaki lima yang masi berada disekitaran taman untuk segerah pindah kepasar sentral yang 
disediakan pemerintah untuk lokasi berdaganggnya yang baru.

Satpol PP seringkali memberikan teguran-teguran kepada pedagang kaki lima yang masi mendirikan tenda-tenda disekitaran taman, dan ada beberapa pedagang yang memanfaatkan pekerangan rumah warga yang berada disekitaran Taman Sulikan sebagai lapak berdangganya. Dan adanya para pedagang baru yang tiap tahunnya mengisi trotoar jalan taman sulikan sebagai lokasi barunya. Adapaun jumlah pedagang yang berdagang ditrotoar Jalan Taman Sulikan yaitu sebagai berikut. Dalam melakukan relokasi pedagang kaki lima yang berada ditrotoar jalan taman sulikan pemerintah perlu melakukan peningkatan-peningkatan strategi yang mencangkup penyusunan misi tujuan dan strategi, motivasi, sitem fugsi dan kelompok budaya. Serta dalam melakukan penataan pedagang kaki lima pemerintah perlu melakukan pemeberian izin usaha, pemberian modal dan pemberian sarana dan prasarana. Adapun

strategi-strategi yang dilakukan pemerintah yaitu sebagai berikut:
Yang terdapat dalam Tesis, Agus Susilo (2011) Pedagang kaki lima merupakan pedagang kreatif yang memanfaatkan lahan kosong dan trotoar jalan yang dijadikan sebagai lapak berdagangnya. Dan Pedagang kaki lima merupakan segelintir masyarakat yang menggunakan area larangan berdagang sebagai lokasi untuk menyambung perekonominnya. Permasalahan pedagang kaki lima tidak kunjung selesai disetiap daerah yang ada di indonesia, permasalahan pedagang kaki lima tiap tahun menuai permasalahan yang dimana pemerintah daerah setiap saat memberikan himbaun kepada masyarakat yang berprofesi sebagai pedagang kaki lima untuk selalu menciptakan kebersihan, keindahan dan kerapian kota yang sering dikenal dengan istilah 3K. Dengan ditetpkannya perda mengenai PKL, yang termuat dalam Reprsentasi dari Perpres No 125 Tahun 2012 tentang

Penetapan, Pembinaan dan Pemberdayaan Pedagang Kaki Lima dan Pemendagri No 41 Tahun 2012 Tentang Penetapan dan Pemberdayaan PKL. Penelitian ini 
menjelaskan bagaimana pemerintah melakukan relokasi pedagang kaki lima dalam menciptakan kawasan taman sulikan sebagai ruang terbuka hijau dengan memindahakan pedagang kaki lima yang sebelumnya ada ditaman sulikan dipindahkan ke pasar sentral masamba kabupaten luwu utara. Dalam melakukan relokasi ini ada beberapa instansi terkait yang ikut andil dalam melakukan relokasi pedagang kaki lima.. Strategi pemerintah dalam melakukan relokasi pedagang kaki lima menggunakan beberapa strategi yaitu: penyusunan misi, tujuan dan strategi, motivasi, sistem fungsi dan kelompok budaya. Dan dalam menata pedagang kaki lima pemerintah menggunakan bentuk penataan sebagai berikut: memberikan izin usaha, pemberian modal dan pemberian sarana dan prasana. Adapun penjelasan mengenai strategi pemerintah dan bentuk penataan pemerintah dalam merelokasi Pedagang Kaki Lima di Kabupaten Luwu Utara sebagai berikut:

Strategi Pemerintah yang dimaksud dan yang terlibat dalam merelokasi Pedangang Kaki Lima yaitu Dinas Lingkungan Hidup,

Dinas Pekerjaan Umum dan Penataan Ruang, dan Satuan Polisi Pamong Paraja (Satpol PP) dalam Aktualisasi Relokasi Pedagang Kaki Lima. Ketiga Instansi Pemerintah tersebut memliki tugas yang berbeda dalam melakukan Relokasi Pedagang Kaki Lima yang terdapat di Taman Sulikan. Dalam melakukan relokasi pedagang kaki lima pemerintah melakukan himbaun kepada masyarakat terutama pedagang kaki lima dan beberapa strategi yang digunakan pemerintah dalam merelokasi pedagangang kaki lima sebagai berikut: Misi adalah merupakan pernyataan hal-hal yang harus dicapai organisasi bagi pihakpihak berkepentingan dalam mencapai sasaran yang telah ditentukan. Dalam menjalankan misi terdapat beberapa tujuan-tujuan yang hendak dicapai sebelum tujuan utama tercapai. dan strategi merupakan suatu hal yang mutlak dimiliki oleh

pemerintah dalam menjalankan misinya untuk mencapai tujuan.

Oleh karena itu dalam melakukan relokasi pada pedagang 
kaki lima pemerintah setempat membutuhkan misi, tujuan dan

strategi untuk mempermudah jalannya relokasi. Motivasi merupakan suatu proses psikologis yang menyebabkan stimulasi, arahan dan kegigihan terhadap sebuah kegiatan yang dilakukan secara sukarela yang diarahkan pada suatu tujuan (Robert Kreitner, 2014).

Motivasi dijadikan sebagai kekuatan oleh pemerintah dalam melakukan pendekatan terhadap masyarakat untuk merelokasi pedagang kaki lima. Pedagang kaki lima merupakan sebagian masyarakat yang memanfaatkan tanah milik negara sebagai lapak berdagangnya, dengan adanya motivasi yang diberikan pemerintah terhadap masyarakat dapat membuka wawasan masyarakat untuk lebih menegetahui tentang lokasi-lokasi mana saja yang tidak diperuntuhkan untuk perdagangan.

Sistemfungsi/sisteminformasi merupakan suatu hal yang sangat penting dalam mencapai tujuan yang telah ditentukan. Sistem fungsi digunakan sebagai bentuk penginformasian yang dilakukan pemerintah dalam memberi informasi atau menerima informasi. Dengan adanya sistem fungsi yang dilakukan pemerintah dapat memudahkan pemerintah dalam melakukan sosialisasi kepada masyarakat dengan tepat. Kelompok budaya merupakan budaya yang ada dalam kelompok tersebut. Dalam artian kebiasan-kebiasaan yang ada dalam kelompok itu, yang menjadikan sebagai ciri khasnya dari daerah tersebut. Kelompok budaya sangat berpengaruh dalam lingkungan sosial, karena adanya aturan-aturan yang telah membudaya dan mengikat masyarakat yang terdapat pada daerah tersebut.

Kelompok budaya dijadikan sebagai aturan yang harus dipatuhi didalam melakukan sebuah hal yang ingin dicapai. Kelompok budaya sangat berperan penting dalam pembangunan suatu daerah. Bentuk Penataan Pemerintah. Dalam menata pedagang kaki lima ketiga Instasi

Pemerintah Dinas Lingkungan Hidup, Dinas Pekerjaan Umum dan Penataan Ruang, dan Satuan Polisi

Pamong Praja (Satpol PP) memberikan beberapa bantuan 
kepada pedagang kaki lima dalam penataan ruang tata hijau taman sulikan agar pedagang kaki lima tidak berjualan disembarang tempat dan adapun bentuk penataan

pemerintah dalam merelokasi pedagang kaki lima sebagai berikut:

Modal Menurut Riyanto dalam Jurnal Srihandayani (2010) dengan tersedianya modal maka usaha akan berjalan lancar sehingga akan mengembangkan modal itu sendiri melalui suatu proses kegiatan usaha. Modal yang digunakan dapat merupakan modal sendiri atau merupakan modal kombinasi antara modal pinjaman dan modal dari pemerintah. Kumpulan berbagai sumber modal akan membentuk

suatu kekuatan modal yang ditanamkan guna menjalankan usaha. Modal merupakan suatu alat yang digunakan dalam membuka usaha, dengan adanya modal masyarakat dapat membuka lapangan kerja tersendiri dan memberikan peluang bagi masyarakat lain untuk mendapatkan pekerjaan. Dengan adanya modal dari pemerintah masyarakat dapat mengembangkan potensi yang dimilikinya.
Pemberian izin yang terdapat dalam jurnal Wijaya (2015) adalah pengikatan-pengikatan pada suatu peraturan, izin pada umumnya didasarkan pada keinginan pembuat undang-undang untuk mencapai suatu tatanan tertentu atau untuk menghalangi keadaan yang buruk.

Pemberian izin dikeluarkan pemerintah dalam rangka memberikan tatanan kepada masyarakat dalam membuka usaha.

Dengan adanya surat izin yang dikeluarkan oleh pemerintah masyarakat akan memiliki wewenang dalam membuka usaha tanpa ada pihak yang menghadang dalam pendirian usaha masayarakat. Dengan adanya surat izin membuka usaha masyarakat akan mudah membuka lapangan pekerjaan dan mengurangi jumlah pengangguran yang ada serta memberikan pengaruh pada kesejahteraan suatu daerah. Sarana dan prasarana merupakan bantuan fisik yang diberikan pemerintah kepada masayarakat dalam mengembangkan usahanya, dengan Hidayanti (2014) adanya sarana dan prasarana yang diberikan pemerintah kepada masyarakat dapat 
memudahkan masyarakat dalam melakukan proses berdagang dan mencapai tujuan yang mereka inginkan. Sarana dan prasarana sangat penting bagi masyarakat dalam membuka usaha kecil-kecilan bagi masyarakat pemula dalam membuka usaha.

\section{KESIMPULAN}

Masalah utama yang dihadapi oleh pedagang kaki lima adalah masalah tempat (lokasi berdagang). Melihat kondisi yang terjadi di Masamba Kabupaten Luwu Utara dimana pedagang kaki lima telah disediakan lokasi berdagang baru yang berada di pasar sentral. Sehingga pedagang kaki lima tidak lagi menjajakan daganganya sekitaran taman sulikan dan mengembalikan hak pejalan kaki dalam menikmati trotoar jalan. Dalam merelokasi pedagang kaki lima ini dibutuhkan peran aktif dari pemerintah setempat dalam memberdayakan pedagang kaki lima. Kurangnya lapangan kerja yang ada di Luwu Utara membuat sebagian Masyarakat Luwu Utara beralih profesi menjadi seorang pedagang kaki lima dalam memenuhi kebutuhan ekonomi.

Dalam merelokasi pedagang kaki lima maka Pemerintah Daerah melakukan penataan pedagang kaki lima yang tak kunjung habis di kabupaten luwu utara. Dalam penataan pedagang kaki lima ini dapat mewujudkan keindahan estetika di RTH Kota Masamba dan pedagang kaki lima yang berada di Kabupaten Luwu Utara dapat terorganisir secara baik dengan adanya bantuan dari pemerintah berupa surat izin usaha, modal, saranan dan prasarana dari pemerintah. Karena Kota Masamba memiliki sebagian masyarakat yang berprofesi sebagai pedagang kaki lima.

Dalam memberdayakan pedagang kaki lima dibutuhkan peran aktif pemerintah setempat untuk meningkatkan potensi pedagang kaki lima dalam persaingan dunia usaha. Perlu koordinasi yang baik antar para instansi yang menangani pedagang kaki lima di Kabupaten Luwu Utara agar pedagang kaki lima tidak lagi menggunakan area terlarang sebagai lokasi 
berdagangnya. Pemerintah perlu memberikan penyuluhan kepada

pedagang kaki lima dalam memanfaat kan lokasi sebagai tempat berdagang terutama pada area larangan berdagang.

Pemerintah daerah harus memiliki ketegasan dalam memberikan himbuan kepada pedagang kaki lima tentang hak-hak pejalan kaki diatas trotoar jalan. Dalam melakukan reloksi diperlukan keterbukaan antara instansi pemrintahan yang menangani relokasi pedagang kaki lima degan masyarakat terutama dengan pedagang kaki lima.

\section{DAFTAR PUSTAKA}

Eddy Yunus. 2016. Manajemen Strategi. Yogyakarta: CV Andi Offset

Jhingan. 2014 Ekonomi Pembangunan dan Perencanaan.

D.Grito.Jakarta:Rajawali Pera.

Makmur. 2009.Teori Manajemen Stratejik Dalam Pemerintahan dan Pembangunan. PT Refika Aditama.

Sedarmayanti. 2014 Manajemen Strategi Bandung: PT Aditama. Jurnal, Srihandayani (2010) Manajemen dan Kewirausahaan. Tia Marlinda Sari, (2010) Manajemen Strategi Pemerintahan Dinas Perindustrian

Dalam Pengembangan Usaha Kecil Menegah (Studi UKM Industri Kerajinan Tapis Di Bandar Lampung)

Tesis, Agus Susilo. 2011 Program Megister Perencanaan dan Kebijakan Publik,

Skripsi Muhammad Nur. 2015 Strategi Peningkatan Usaha Pedagang Kaki Lima Di Kecamatan Turikale Kabupaten Maros.

Wijaya. 2015 Kewenangan Pemerintah Daerah Dalam Penerbitan Surat Izin. Ilmu Hukum. 
Hidayanti, 2014 Ruang Lingkup

Sarana dan Prasarana. Ilmu

Pemerintahan 